\title{
Hec1/Nek2 Mitotic Pathway Inhibitor INH1 Inhibits the Cell Kinetic Parameters of A549 and HeLa Cells
}

\author{
İdil Çetin \\ https://orcid.org/0000-0002-3961-6422 \\ Istanbul University, Faculty of Science, Department of Biology, Istanbul, Turkey. \\ Editor-in-Chief: Alexandre Rasi Aoki \\ Associate Editor: Sinvaldo Baglie
}

Received: 2021.04.13; Accepted: 2021.08.16.

*Correspondence: idil.cetin@istanbul.edu.tr; Tel.: +90-212-4555700 (I.Ç.).

\section{HIGHLIGHTS}

- INH1 inhibits cell proliferation of A549 and HeLa cells.

- INH1 has cytostatic and cytoskeletal effects at different concentrations.

- INH1 can be used for new cancer treatment protocols.

Abstract: In this current study, antiproliferative effect of Hec1/Nek2 Mitotic Pathway inhibitor INH1 was investigated in adenocarcinomic human alveolar basal epithelial cells A549 and human cervix carcinoma HeLa cell lines in vitro. To this end cell index values by xCELLigence Real-Time Cell Analysis DP instrument, mitotic index, BrdU proliferation assay and apoptotic index analysis were used. The results of the current study showed that INH1 had cytostatic and cytoskeletal effects on A549 and cytostatic effect on HeLa cells. The $\mathrm{IC}_{50}$ concentration was determined as $56 \mu \mathrm{M}$ with the xCelligence device for both cell lines. $\mathrm{IC}_{50}$ concentration was used for all other parameters. While this concentration decreased the mitotic index BrdU proliferation values, it increased the apoptotic index values of both of cell lines. There were significant differences between the control and the experimental groups $(p<0.05)$. The results of the present study suggest that INH1 may serve as a promising treatment option for different types of cancer.

Keywords: HeLa; A549; xCelligence; cell kinetics.

\section{INTRODUCTION}

Conventional treatment methods for cancer, defined as uncontrolled cell division, are surgery, chemotherapy and radiotherapy. However, these treatment methods are insufficient in the treatment of many types of cancer due to their various limitations. Targeted therapy is one of the important option for cancer treatment [1]. Targeted therapy, which refers to a new generation of drugs, interferes with a specific molecular target that has an important role in tumor formation and development [2].

Proper separation of chromosomes during mitosis is important to avoid genetic instability, one of the hallmark of cancer [3]. NDC80/Hec1 is basic molecules of the mitotic kinetochore complex. Hec1 has an important role in the control of mitotic cell division and survival [4]. It is known that the Ndc80 complex is required for the kinetochore uptake of mitotic checkpoint proteins [5, 6]. Ndc80/Hec1 is an attractive target that can be used for cancer therapy. Various strategies are being developed that aim to inhibit the activity of this complex structure [7]. 
While Hec1 is expressed low in organs with low cell division rate, it is highly expressed in transformed cells [8]. Hec1 is overexpressed in many types of human cancers [4, 9, 10]. Also Hec1 overexpression leads to tumor formation in vivo [11].

It has been determined that INH1, a small molecule, specifically binds to Hec1 and disrupts the Hec1 / Nek2 interaction. The administration of INH1 to cells causes a decrease in the level of the kinetochoredependent Hec1 as well as the level of the Nek2 protein. This eventually leads to metaphase chromosome misalignment, spindle deflection, and eventual cell death [4].

In this study, it was aimed to investigate the antiproliferative effects of the Hec1 inhibitor INH1 alone on lung and cervical cancer cell lines, which are independent cancer types in cellular level.

\section{MATERIAL AND METHODS}

\section{Cell Culture}

A549 and HeLa cells used in the experiments were provided by American Type Culture Collection (ATTC Manassas, VA, USA). Both of cell lines regularly underwent two passages per week. A549 cell line was cultured in RPMI 1640 (Invitrogen, Carlsbad, CA, USA) and HeLa cell line was cultured in M199 (Invitrogen, Carlsbad, CA, USA). containing penicillin and streptomycin (50 units $/ \mathrm{mL}$ for both) and $10 \%$ bovine serum at $37^{\circ} \mathrm{C}$ and $5 \% \mathrm{CO} 2$.

\section{Inhibitor Concentrations}

$40 \mu \mathrm{M}, 60 \mu \mathrm{M}$ and $80 \mu \mathrm{M}$ concentrations were prepared by diluting a total of $1 \mathrm{mM} \mathrm{INH} 1(\mathrm{~N}-(4-[2,4-$ dimethyl-phenyl]-thiazol-2- yl)-benzamide) (Tocris) stock solution.

\section{Cell Index}

For cell index analysis and determination of IC50 concentration, xCELLigence DP system was used. Backround measurements were taken before starting the experimental process. For this purpose, $100 \mu \mathrm{L}$ appropriate medium was added to wells and the impedance of each well was measured. Then $8000 \mathrm{cell} / \mathrm{well}$ and $6000 \mathrm{cell} /$ well were seeded for A549 and HeLa cell lines respectively. The final volume was set to 200 $\mu \mathrm{L}$. 16 well E-Plates were incubated at $37^{\circ} \mathrm{C}$ with $5 \% \mathrm{CO} 2$ and monitored on the RTCA system at 15 -minute time intervals for up to $24 \mathrm{~h}$ without treatment and following $72 \mathrm{~h}$ with treatment. The DP unit is wired to an external laptop running the xCELLigence software (version 1.2.1).

\section{Mitotic Index}

For determination of mitotic cells, cells were planted in 24-well plates containing $3 \times 104$ cells for both cell lines. After cell seeding, cells were incubated $24 \mathrm{hrs}$. Cells treated with optimum INH1 concentration were fixed with Carnoy's fixative at the end of the experimental periods. Then Feulgen method was applied and stained with Giemsa. For analysing MI, approximately 3000 cells were counted with light microscope for each experimental group.

\section{BrdU Proliferation Assay}

BrdU (5-bromo-2'-deoxyuridine) was used to determine the DNA synthesis rate of A549 and HeLa cells after administration of IC50 concentration of INH1. This test is based on the determination of BrdU that binds to the genomic DNA of proliferating cells. BrdU was prepared according to manufacturer's protocol and then detected via spectrophotometric method.

\section{Apoptotic Index}

6-diamidino-2-phenylindole (DAPI) was used to determine the apoptotic cells. DAPI, a fluorescent dye, stains the nucleus of apoptotic cells. After culturing and inhibitor treatment, cells fixed with methanol: FTS mixture until staining was performed. For removing the dye PBS was used. A fluorescent microscope was used to identify apoptotic cells. 


\section{Statistical Analysis}

All parameters ( $\mathrm{MI}, \mathrm{BrdU} \%$ and $\mathrm{Al}$ ) were evaluated according to the controls and each other. Therefore, in order to analyze the results one-way Anova test, Dunnett's test and Student's t-test were used. These statistical analyses were performed using SPSS statistics software (V22.0 IBM, Armonk, NY, USA). In the tests $p<0.05$ level of significance was accepted.

\section{RESULTS}

\section{Cell Index}

Cell index values obtained from $x$ Celligence real-time cell analysis system showed that application of INH1 on A549 and HeLa cells had significant antiproliferative effects. For both A549 and HeLa cells, INH1 concentrations of $40 \mu \mathrm{M}, 60 \mu \mathrm{M}$ and $80 \mu \mathrm{M}$ were used throughout the experimental period. When the graphical curves of A549 cells are examined, it is thought that $40 \mu \mathrm{M}$ INH1 concentration has cytostatic effect, while $60 \mu \mathrm{M}$ and $80 \mu \mathrm{M}$ INH1 concentration has cytoskeletal effect (Figure 1). Graph curves of HeLa cells showed the cytostatic effect for all concentrations (Figure 2). As indicated in Figure 3 and 4, the IC50 value for A549 and HeLa cells were determined as $56 \mu \mathrm{M}$ according to the data analysis performed using xCelligence DP software.

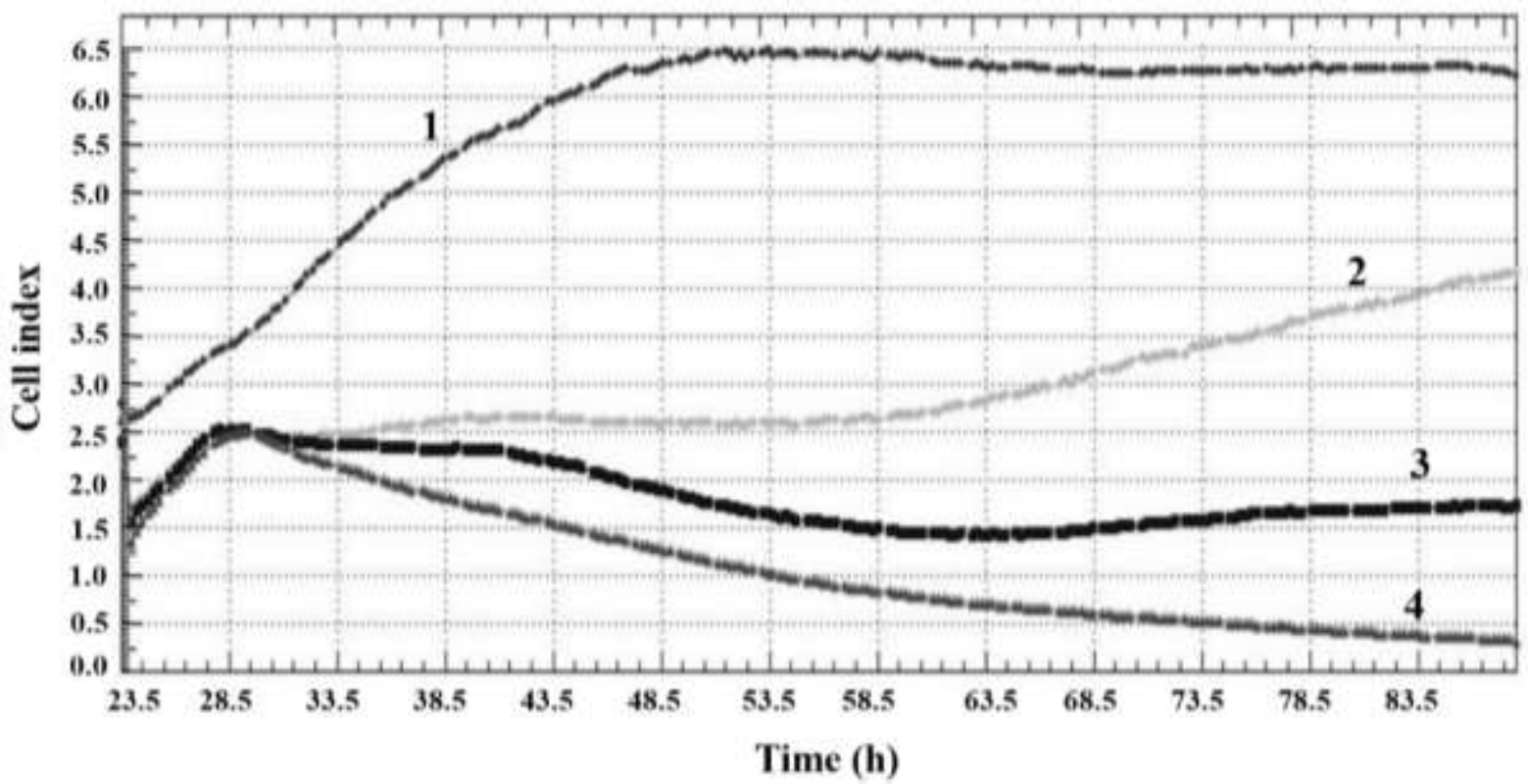

Figure 1. Cell index values of $A 549$ cells treated with $40 \mu \mathrm{M}, 60 \mu \mathrm{M}$ and $80 \mu \mathrm{M}$ concentrations of INH1 obtained from xCelligence Real-Time Cell Analysis (RTCA) system (Line1: Control, Line 2: $40 \mu \mathrm{M}$, Line 3: $60 \mu \mathrm{M}$ and Line 4: $80 \mu \mathrm{M}$ ).

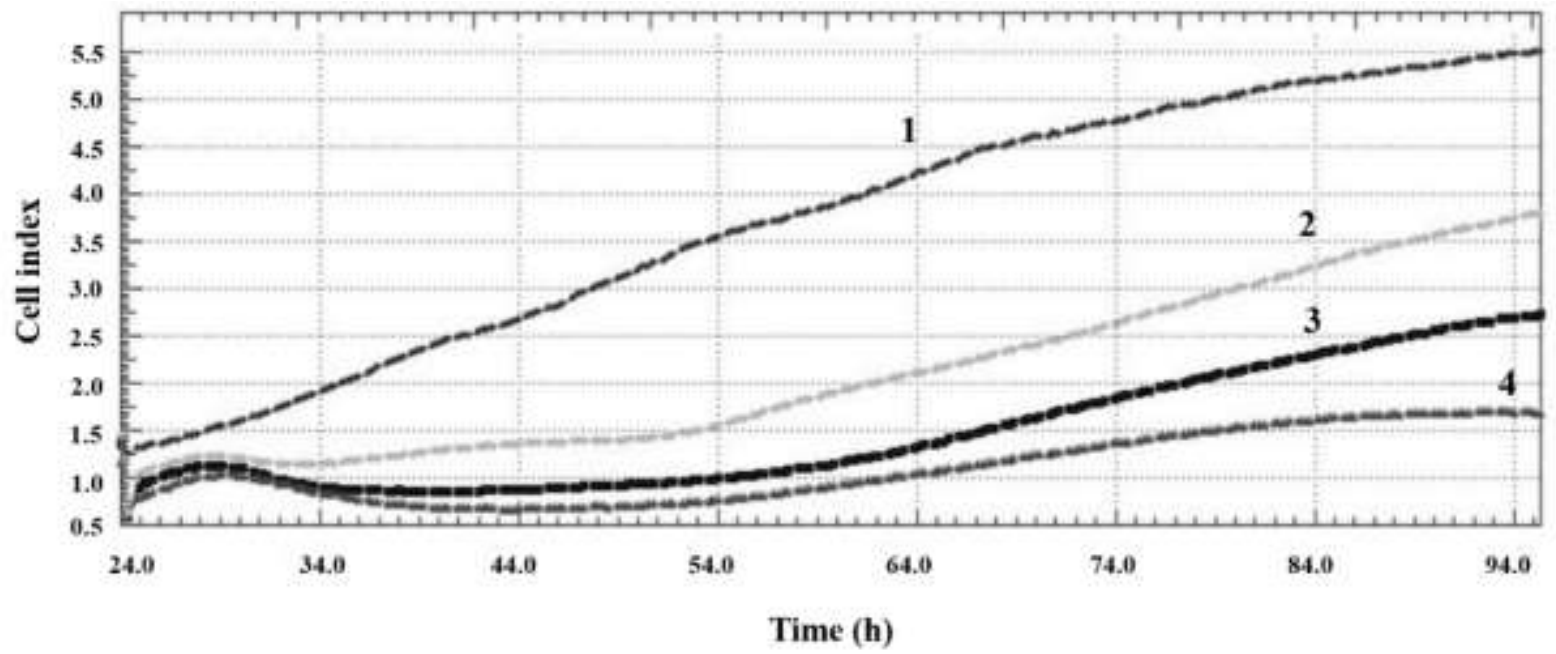

Figure 2. Cell index values of HeLa cells treated with $40 \mu \mathrm{M}, 60 \mu \mathrm{M}$ and $80 \mu \mathrm{M}$ concentrations of INH1 obtained from xCelligence Real-Time Cell Analysis (RTCA) system (Line1: Control, Line 2: $40 \mu \mathrm{M}$, Line 3: $60 \mu \mathrm{M}$ and Line 4: $80 \mu \mathrm{M}$ ). 


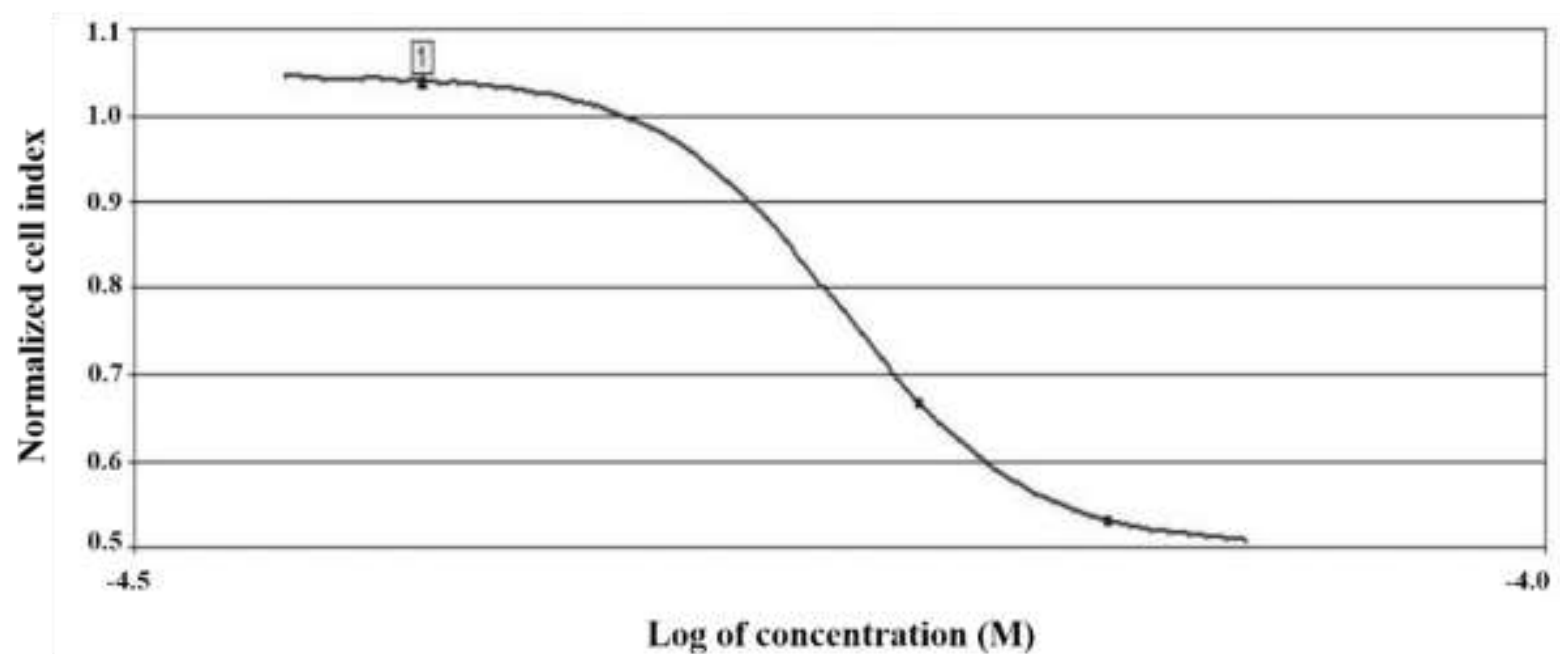

Figure 3. $\mathrm{IC}_{50}$ values obtained from the $\mathrm{xCelligence} \mathrm{real-time} \mathrm{cell} \mathrm{analysis} \mathrm{system.} 56 \mu \mathrm{M}$ of $\mathrm{INH} 1$ concentration was determined to be the $\mathrm{IC}_{50}$ value for $\mathrm{A} 549$ cells.

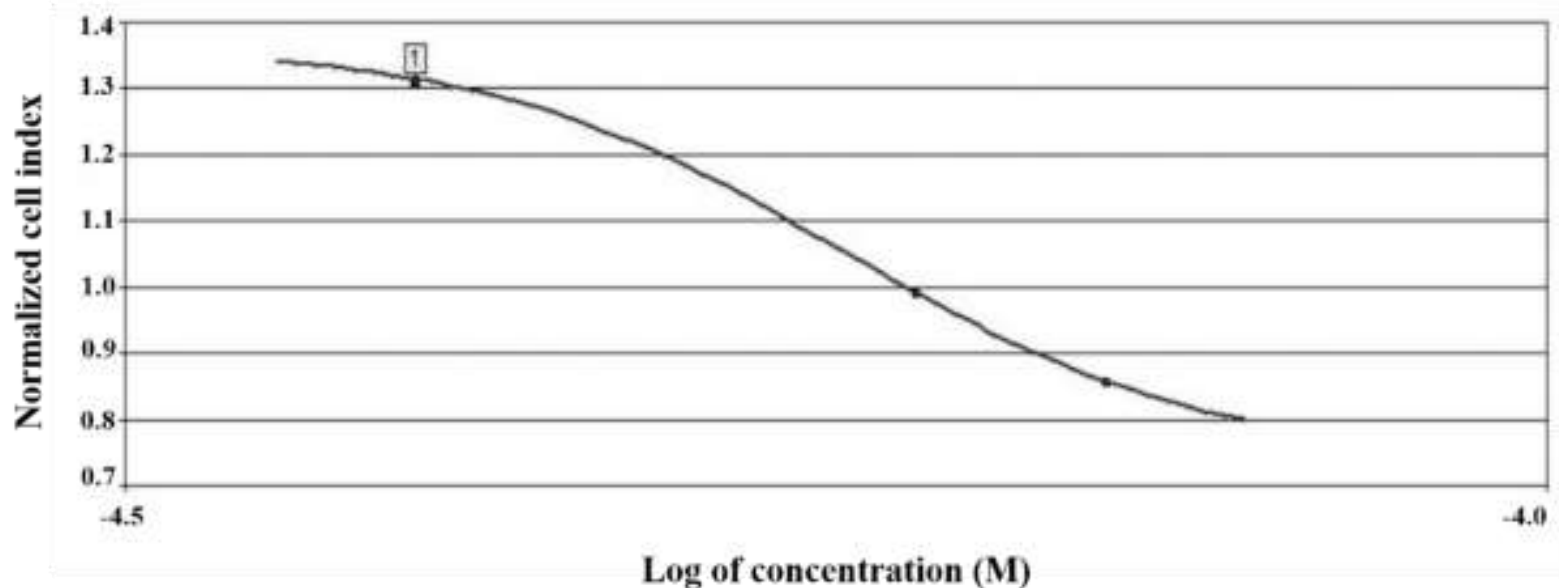

Figure 4. IC 50 values obtained from the $x$ Celligence real-time cell analysis system. $56 \mu \mathrm{M}$ of INH1 concentration was determined to be the $\mathrm{IC}_{50}$ value for HeLa cells.

\section{Mitotic Index}

The values obtained by applying the $56 \mu \mathrm{M}$ optimum concentration of INH1 to A549 and HeLa cells are shown in Figure 5 and 6 . The results showed that this concentration decreased the mitotic index values of A549 cell line from 3,57\% to 2,54\% at $24 \mathrm{~h}$; from $4,96 \%$ to $2,04 \%$ at $48 \mathrm{~h}$ and $5,83 \%$ to $1,47 \%$ at $72 \mathrm{~h}$. Mitotic index values belong to HeLa cells decreased from 3,18 \% to 2,21\% at $24 \mathrm{~h}$; from 3,75 \% to $1,68 \%$ at $48 \mathrm{~h}$ and $4,91 \%$ to $1,27 \%$ at $72 \mathrm{~h}$. The differences between the control and all experimental groups were statistically significant $(\mathrm{p}<0.05)$. 


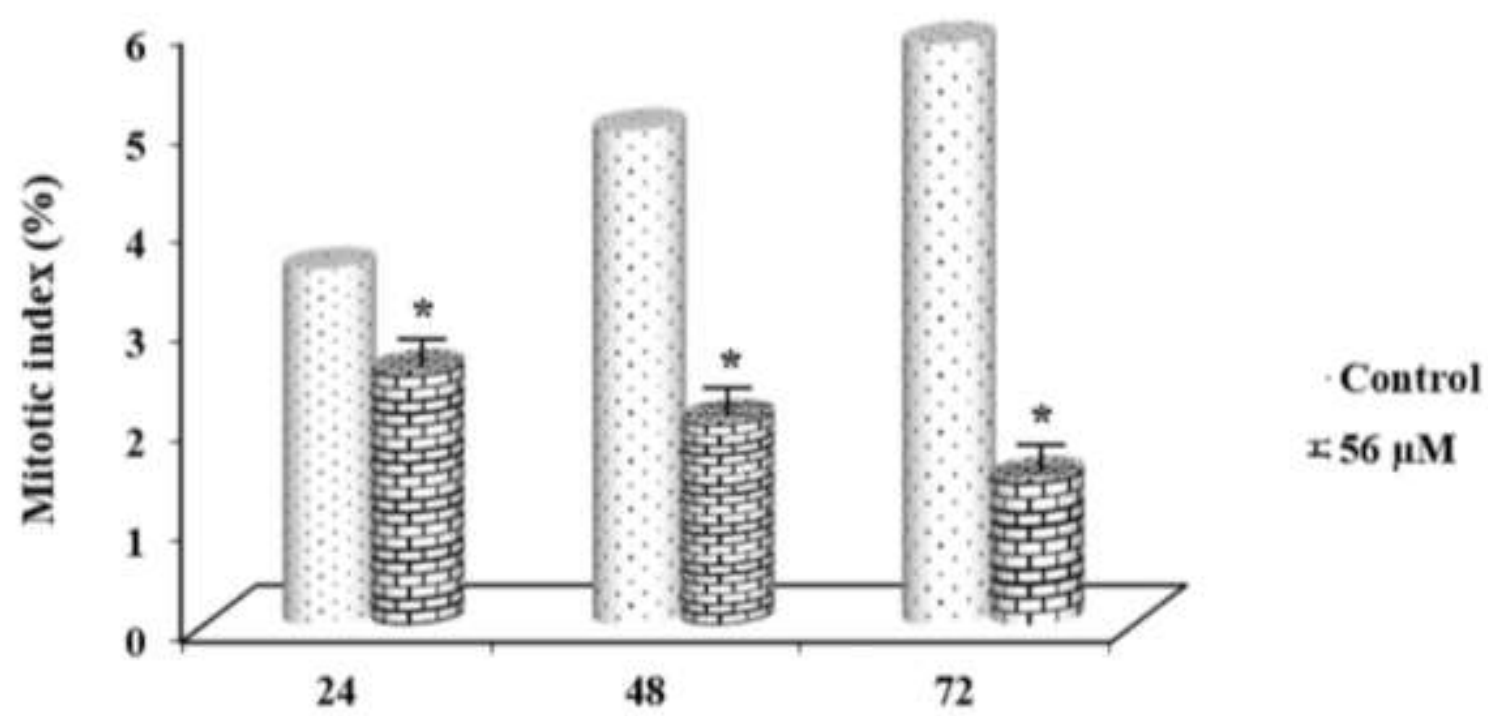

Time (h)

Figure 5. Mitotic index values of A549 cells treated with $56 \mu \mathrm{M}$ INH1 for $24-72 \mathrm{~h}(\mathrm{p}<0.05)$.

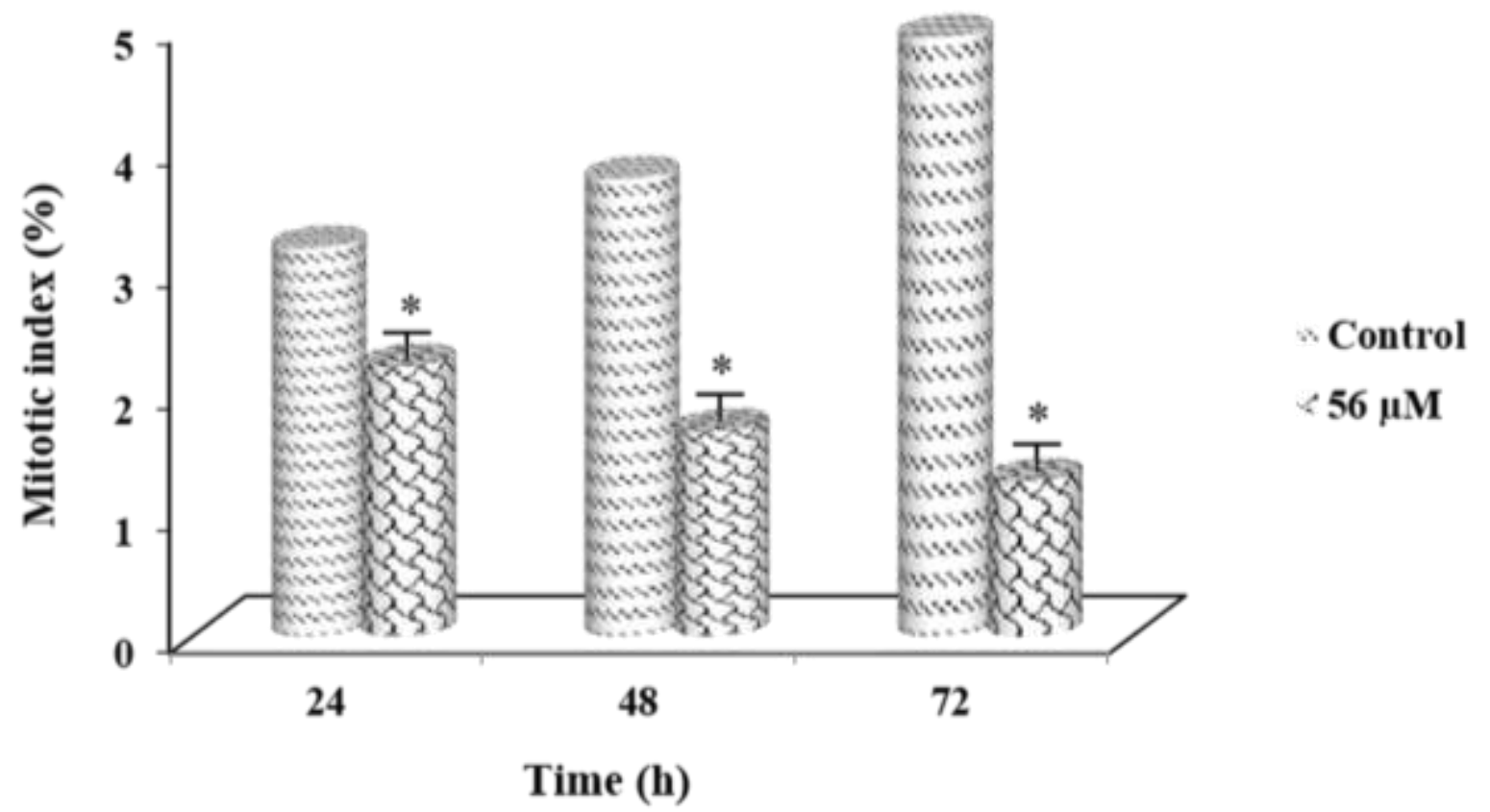

Figure 6. Mitotic index values of HeLa cells treated with $56 \mu \mathrm{M} I N H 1$ for $24-72 \mathrm{~h}(\mathrm{p}<0.05)$.

\section{BrdU Proliferation Assay}

The bromodeoxyuridine (BrdU) values that enable the labeling of cells in the synthesis stage are shown in Figures 7 and 8 . BrdU \% values were 46\%, 33\% and 27\% for the A549 cell line compared to the control groups which were considered $100 \%$. These values were determined as $43 \%, 35 \%$ and $28 \%$ for the HeLa cell line compared to the control groups which were considered $100 \%$. There were significant differences between the control and the experimental groups $(p<0.05)$. 


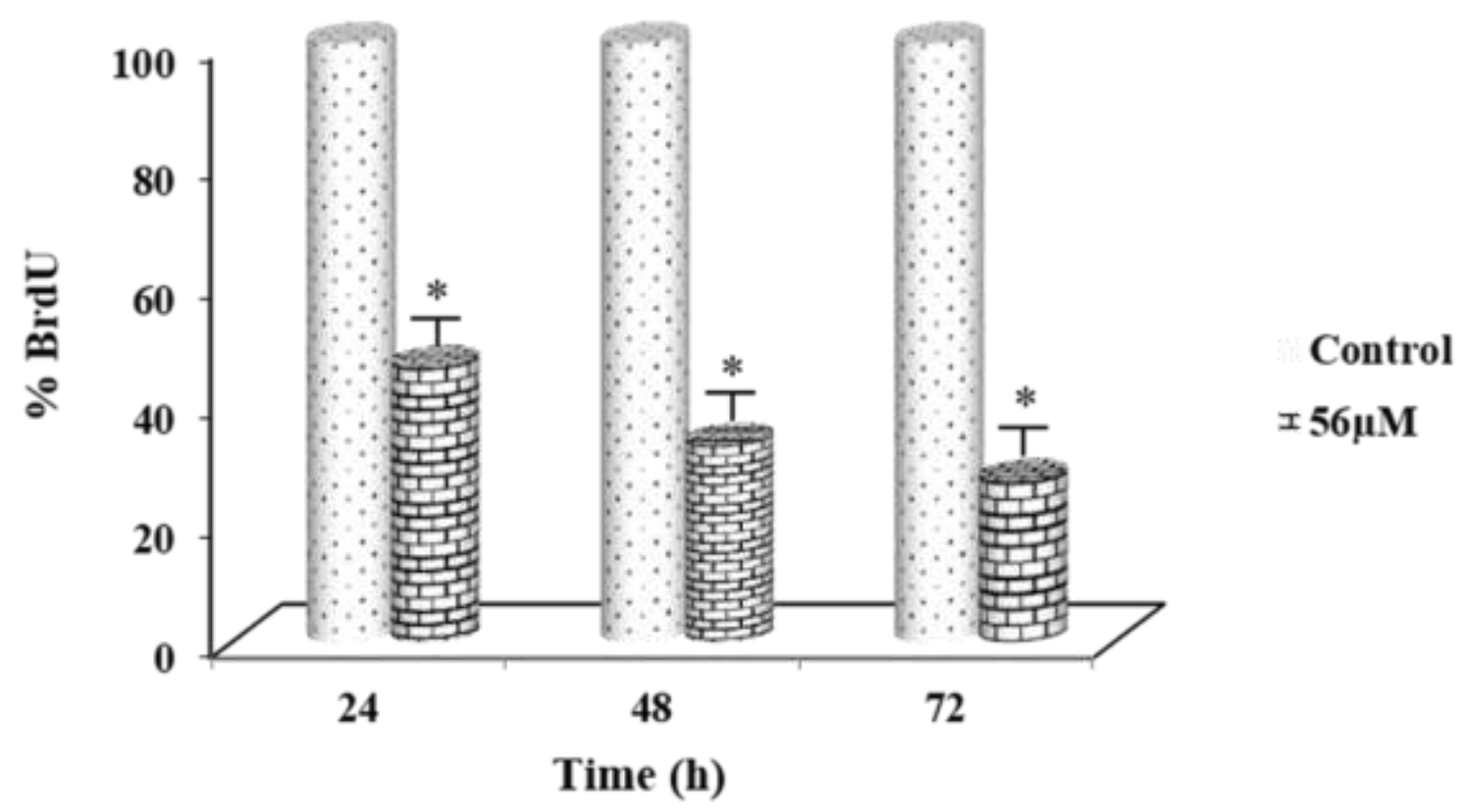

Figure 7. \% BrdU values of A549 cells treated with $56 \mu \mathrm{M}$ INH1 for $24-72 \mathrm{~h}(\mathrm{p}<0.05)$.

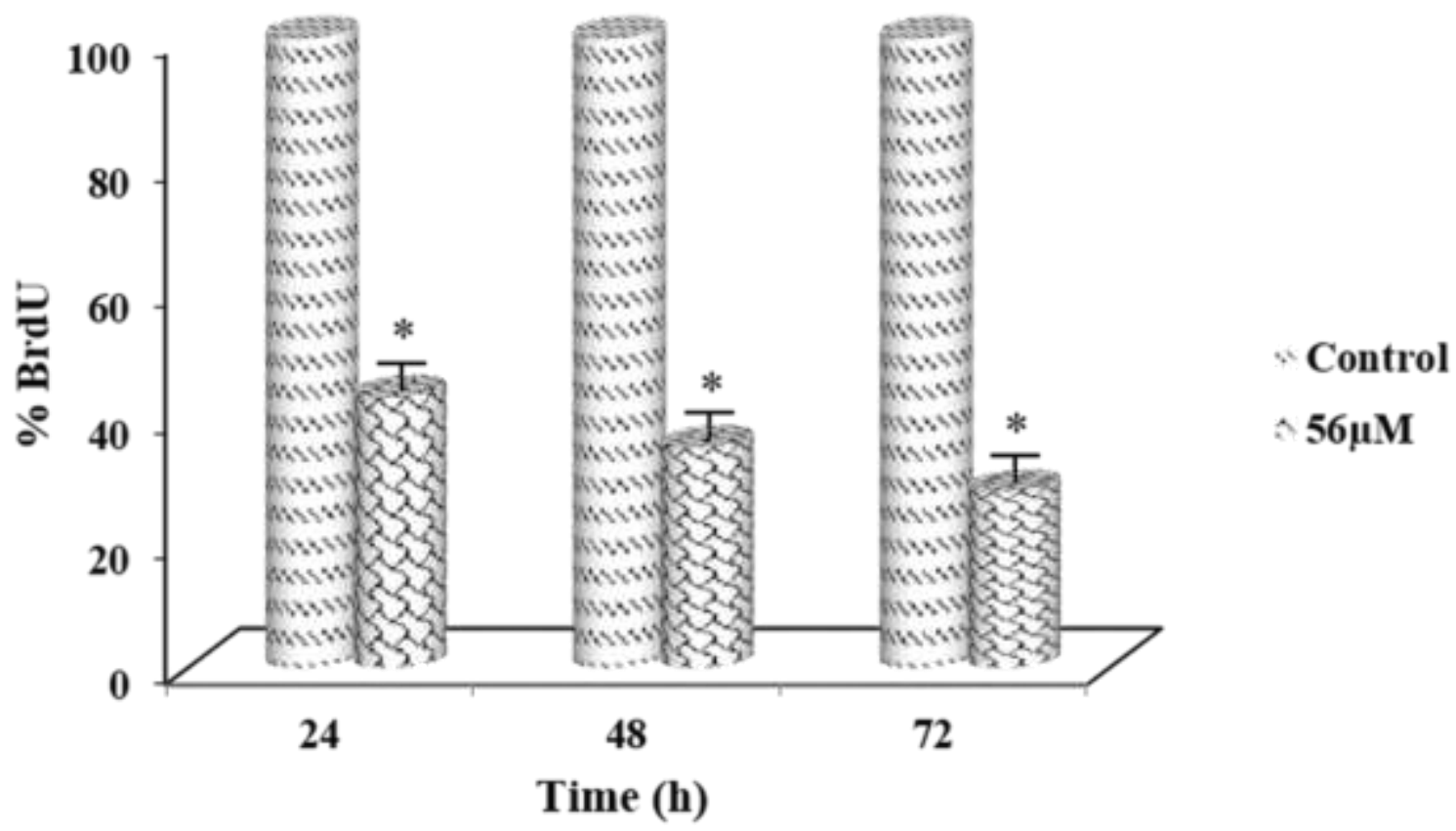

Figure 8. \% BrdU values of HeLa cells treated with $56 \mu \mathrm{M}$ INH1 for 24-72 $\mathrm{h}(\mathrm{p}<0.05)$.

\section{Apoptotic index}

Administration of $56 \mu \mathrm{M}$ concentration of INH1 to A549 and HeLa cells caused apoptotic cell death. Apoptotic index values increased from 3,45 \% to 10,13\% at $24 \mathrm{~h}$; from 4,26\% to $15,32 \%$ at $48 \mathrm{~h}$ and from $5,21 \%$ to $21,97 \%$ at $72 \mathrm{~h}$ for A549 cell line (Figure 9). For HeLa cells apoptotic index values increased from $2,98 \%$ to $11,43 \%$ at $24 \mathrm{~h}$; from $4,12 \%$ to $17,35 \%$ at $48 \mathrm{~h}$ and from $5,54 \%$ to $20,76 \%$ at $72 \mathrm{~h}$ (Figure 10). This decrease was statistically significant $(p<0.05)$. 


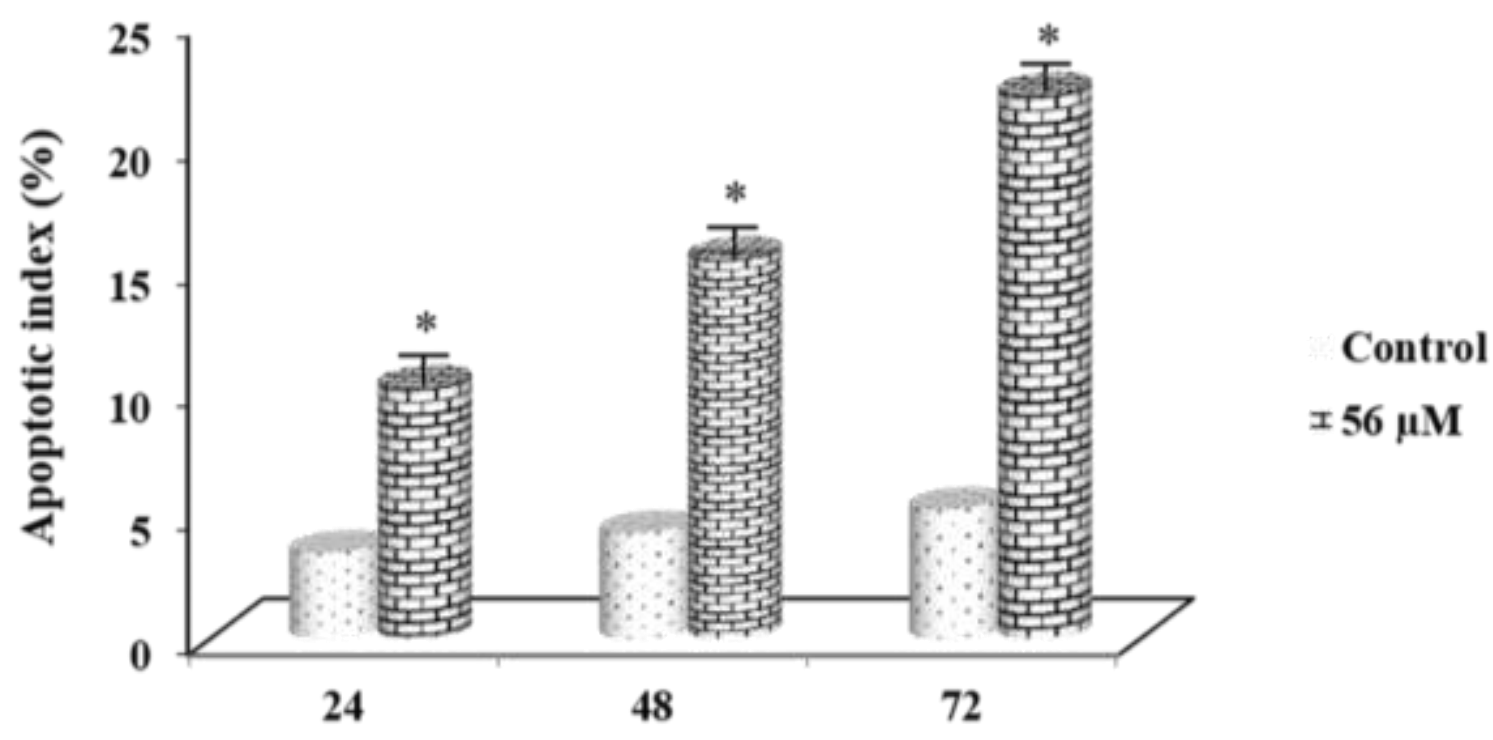

Time (h)

Figure 9. Apoptotic index values of A549 cells treated with $56 \mu \mathrm{M} I N H 1$ for $24-72 \mathrm{~h}(\mathrm{p}<0.05)$.

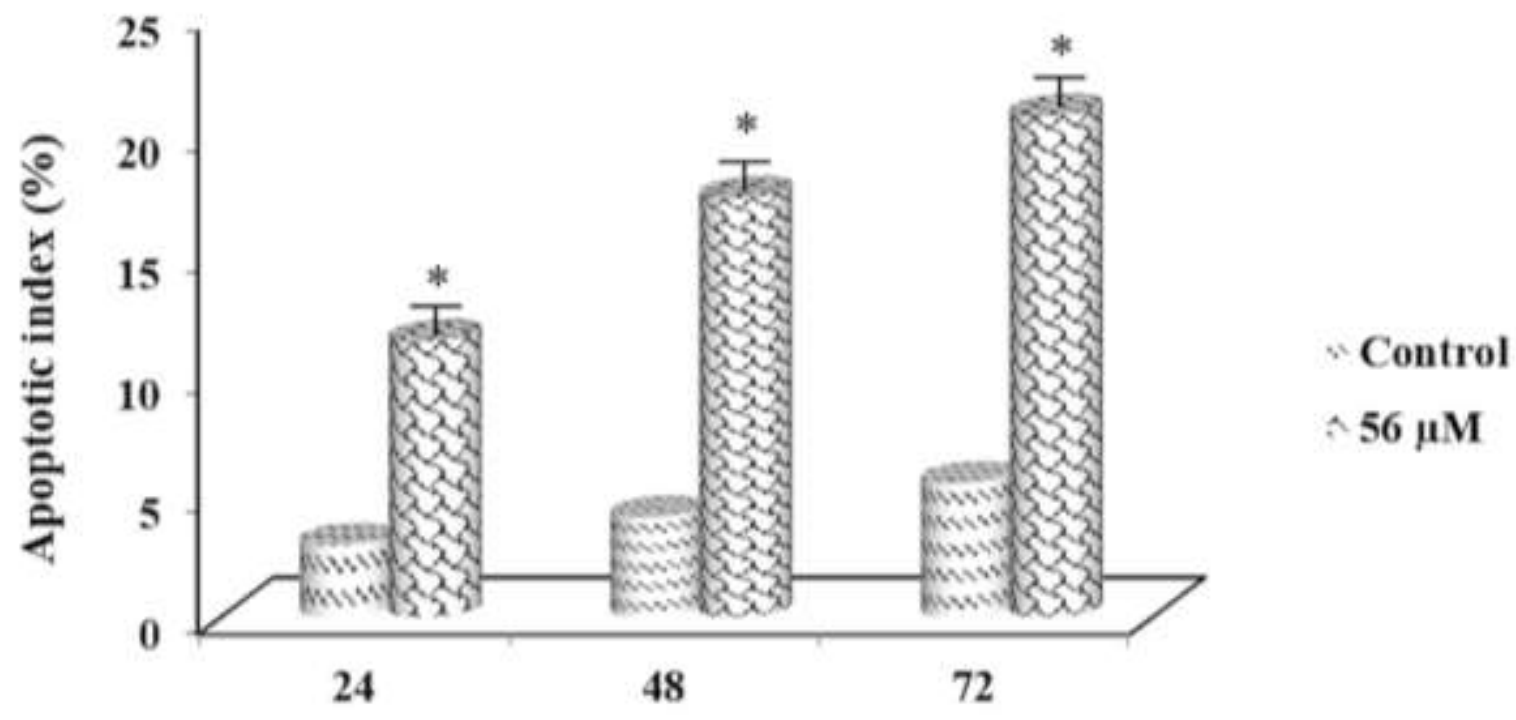

Time (h)

Figure 10. Apoptotic index values of HeLa cells treated with $56 \mu \mathrm{M} I N H 1$ for $24-72 \mathrm{~h}(p<0.05)$.

\section{DISCUSSION}

The existence of a large number of molecules that contribute to cancer formation has led to the need to discover targeted agents that will stop tumor growth. INH1, one of these agents, binds to Hec1 to break its function. As a result of this, abnormal mitotic cell division, induction of apoptosis, and cell death occures [4, 12].

The goal of this study was to evaluate the cytotoxic effects of HEC1 inhibitor INH1 on A549 cells derived from human lung carcinoma and HeLa cells derived from human cervix carcinoma. To this end various cell kinetic parameters including cell index, MI, \% BrdU value and Al cell kinetic parameters were used.

Data from molecular studies have shown that HEC1 is upregulated in brain, liver, breast and lung tumor cells [13]. Upregulation and expression of HEC1 in cells has been associated with tumor grade and prognosis $[14,15]$. Overexpression of HEC1 is shown in cervical, colorectal, breast, lung and gastric cancer cells [8, $15,16]$. 
While $12.8 \%$ of mice overexpressing Hec1 develop lung adenomas, only $1.4 \%$ of mice that do not overexpress Hec1 develop similar tumors [11]. Co-overexpression of Ndc80 has been found in non-small cell lung carcinomas (NSCLC) and its cell lines [15]. These data correlate the increase of Hec1 level in the cell with the tumor phenotype [8].

Small molecule INH1 directly binds to HEC1 and disrupts HEC1/NEK2 interaction. This triggers NEK2 degradation, which will ultimately cause cell death. Studies have shown that INH1 effectively suppresses the proliferation of breast cancer cell lines [4, 12]. Different INH derivatives was shown that they suppressed xenograft tumor growth without obvious toxicity [17].

Inactivation of cellular Hec1 is known to negatively impact mitosis and cell proliferation [5, 18-24]. INH1 treatment causes cell death by causing mitotic defects. To determine the cytotoxic activity of INH1, a panel of human breast cancer cell lines, cervical adenocarcinoma cell line HeLa and the colon cancer cell line HCT116 were used by Wu et al. and INH1 has been shown to inhibit cell proliferation in cell culture [4]. Chuang and colleagues have produced a Hec1 inhibitor that has been tested in phase I clinical trials in different cancer types [25].

In a study, the benefits of the combined use of Hec1/Nek2 inhibitors were shown. In this study, it was shown that the combination of Hec1/Nek2 inhibitor with taxanes, which are frequently used in cancer treatment, improves patient outcomes compared to the use of taxanes alone [26].

In addition, the effects of mitotic kinases such as Nek2 on the epithelial mesenchymal transition (EMT), which plays an important role in processes such as metastasis, have been demonstrated, and therefore, the researchers focused on Hec1 as a critical therapeutic target for EMT [27].

In the present study treatment of independent cell lines A549 and HeLa with INH1 resulted in similar effects at the cellular level. When antiproliferative effects of INH1 on cells were evaluated, INH1 decreased cell proliferation at $56 \mu \mathrm{M}$ optimum concentration for both of cell lines. Data from the real-time cell analysis system showed that INH1 has cytostatic and cytoskeletal effects on cells. While $56 \mu \mathrm{M}$ concentration decreased the mitotic index and BrdU proliferation values, it increased the apoptotic index values of both of cell lines. Changes in all parameters suggest that the clinical use of this inhibitor may reduce tumor growth in different types of cancers and contribute to the treatment protocol.

Funding: This research received no external funding.

Acknowledgments: The present study was supported by the Scientific Research Projects Coordination Unit of Istanbul University (project no. FAB-2017-24315).

Conflicts of Interest: The authors declare no conflict of interest.

\section{REFERENCES}

1. Topçul M, Çetin İ. Endpoint of cancer treatment: targeted therapies. Asian Pac J Cancer Prev 2014; 15: 4395-403.

2. Meiyanto E, Hermawan A, Anindyajati. Natural products for cancer-targeted therapy: citrus flavonoids as potent chemopreventive agents. Asian Pac J Cancer Prev 2012; 13: 427-36.

3. Ferretti C, Totta P, Fiore M, Mattiuzzo M, Schillaci T, Ricordy R et al. Expression of the kinetochore protein Hec1 during the cell cycle in normal and cancer cells and its regulation by the pRb pathway. Cell Cycle 2010; 9: 4174-82.

4. Wu G, Qiu XL, Zhou L, Zhu J, Chamberlin R, Lau J, et al. Small molecule targeting the Hec1/Nek2 mitotic pathway suppresses tumor cell growth in culture and in animal. Cancer Res 2008; 68: 8393-9.

5. Martin-Lluesma S, Stucke VM, Nigg EA. Role of Hec1 in spindle checkpoint signaling and kinetochore recruitment of Mad1/Mad2. Science 2002; 297: 2267-70.

6. Meraldi P, Draviam VM, Sorger PK. Timing and checkpoints in the regulation of mitotic progression. Dev Cell 2004; 7: 45-60.

7. Diaz-Rodriguez E. Targeting the Kinetochore in Cancer Therapy: The Ndc80/Hec1 Complex. Current Drug Therapy 2010; 5: 29-35.

8. Chen Y, Riley DJ, Chen PL, Lee WH. HEC, a novel nuclear protein rich in leucine heptad repeats specifically involved in mitosis. Mol Cell Biol 1997; 17: 6049-56.

9. Bieche I, Vacher S, Lallemand F, Tozlu-Kara S, Bennani H, Beuzelin M et al. Expression analysis of mitotic spindle checkpoint genes in breast carcinoma: role of NDC80/HEC1 in early breast tumorigenicity, and a two-gene signature for aneuploidy. Mol Cancer 2011; 10: 23.

10. Xiao GF, Tang HH. Expression and clinical significance of highly expressed protein in cancer (Hec 1) in human primary gallbladder carcinoma. Xi bao yu fen zi mian yi xue za zhi 2008; 24: 910-2.

11. Diaz-Rodriguez E, Sotillo R, Schvartzman JM, Benezra R. Hec1 overexpression hyperactivates the mitotic checkpoint and induces tumor formation in vivo. Proc Natl Acad Sci USA 2008; 105: 16719-24. 
12. Qiu XL, Li G, Wu G, Zhu J, Zhou L, Chen PL, et al. Synthesis and biological evaluation of a series of novel inhibitor of Nek2/Hec1 analogues. J Med Chem 2009; 52: 1757-67.

13. Pèrez de Castro I, de Càrcer G, Malumbres $M$. A census of mitotic cancer genes: new insights into tumor cell biology and cancer therapy. Carcinogenesis 2007; 28: 899-912.

14. Glinsky GV, Berezovska O, Glinskii AB. Microarray analysis identifies a death-from-cancer signature predicting therapy failure in patients with multiple types of cancer. J Clin Invest 2005; 115: 1503-21.

15. Hayama S, Daigo Y, Kato T, Ishikawa N, Yamabuki T, Miyamoto M, et al. Activation of CDCA1-KNTC2, members of centromere protein complex, involved in pulmonary carcinogenesis. Cancer Res 2006; 66: 10339-48.

16. Kaneko N, Miura K, Gu Z, Karasawa H, Ohnuma S, Sasaki H, et al: siRNA-mediated knockdown against CDCA1 and KNTC2, both frequently overexpressed in colorectal and gastric cancers, suppresses cell proliferation and induces apoptosis. Biochem Biophys Res Commun 2009; 390: 1235-40.

17. Hu CM, Zhu J, Guo XE, Chen W, Qiu XL, Ngo B et al. Novel small molecules disrupting HEC1/NEK2 interaction ablate tumor progression by triggering NEK2 degradation through a death-trap mechanism. Oncogene 2015; 34 : 1220-30.

18. DeLuca JG, Moree B, Hickey JM, Kilmartin JV, Salmon ED. hNuf2 inhibition blocks stable kinetochore-microtubule attachment and induces mitotic cell death in HeLa cells. J Cell Biol 2002; 159: 549-55.

19. Deluca JG, Dong Y, Hergert P, Strauss J, Hickey JM, Salmon ED et al: Hec1 and nuf2 are core components of the kinetochore outer plate essential for organizing microtubule attachment sites. Mol Biol Cell 2005; 16: 519-31.

20. Lin YT, Chen Y, Wu G, Lee WH: Hec1 sequentially recruits Zwint-1 and ZW10 to kinetochores for faithful chromosome segregation and spindle checkpoint control. Oncogene 2006; 25: 6901.

21. Fry AM, Descombes $P$, Twomey $C$, Bacchieri R, Nigg EA: The NIMA-related kinase X-Nek2B is required for efficient assembly of the zygotic centrosome in Xenopus laevis. J Cell Sci 2000; 113: 1973-84.

22. Sonn S, Khang I, Kim K, Rhee K: Suppression of Nek2A in mouse early embryos confirms its requirement for chromosome segregation. J Cell Sci 2004;117: 5557-66.

23. Fletcher L, Cerniglia GJ, Yen TJ, Muschel RJ: Live cell imaging reveals distinct roles in cell cycle regulation for Nek2A and Nek2B. Biochimica et biophysica acta 2005; 1744: 89-92.

24. Prigent C, Glover DM, Giet R: Drosophila Nek2 protein kinase knockdown leads to centrosome maturation defects while overexpression causes centrosome fragmentation and cytokinesis failure. Exp Cell Res 2005; 303: 1-13.

25. Shih-Hsien Chuang SH, Lee YSE, Huang LYL, Chen CK, Lai CL, Lin YH, et al. Discovery of T-1101 tosylate as a first-in-class clinical candidate for Hec1/Nek2 inhibition in cancer therapy. Eur. J. Med. Chem. 2020; 191:1-15.

26. Roberts MS, Sahni JM, Schrock MS, Piemonte KM, Weber-Bonk KL, Seachrist DD, et al. LIN9 and NEK2 are core regulators of mitotic fidelity that can be therapeutically targeted to overcome taxane resistance. Cancer Res 2020; 80 (8): 1693-1706.

27. Colón-Marrero S, Jusino S, Rivera-Rivera Y, Saavedra HI. Mitotic kinases as drivers of the epithelial-tomesenchymal transition and as therapeutic targets against breast cancers. Exp. Biol. Med. 2021; 246: 1036-44.

(c) 2021 by the authors. Submitted for possible open access publication under the terms and conditions of the Creative Commons Attribution (CC BY NC) license (https://creativecommons.org/licenses/by-nc/4.0/). 